\title{
https://doi.org/10.52240/1857-2367.2020.2(21).24 \\ PILOSELLA FLAGELLARIS (WILLD.) ARV.-TOUV. (ASTERACEAE) - VULNERABLE TAXON IN THE FLORA OF THE REPUBLIC OF MOLDOVA
}

\author{
Olga IONIŢA \\ “Al. Ciubotaru” National Botanical Garden (Institute), \\ Chisinau, Republic of Moldova
}

Abstract: New data on the distribution and the study of the populations of the rare species Pilosella flagellaris (Willd.) Arv.-Touv. (Asteraceae) in the natural habitats of the Republic of Moldova are presented in the article.

Key words: flora of the Republic of Moldova, Pilosella flagellaris, Asteraceae, rare taxa, new data.

The species Pilosella flagellaris (Willd.) Arv.-Touv. - was identified for the first 
time, in the flora of the Republic of Moldova, in 2010, when a monographic study on the Asteraceae family (subfam. Cichorioideae Kitam.) was conducted [1]. In the studied territory, Pilosella flagellaris grows: near Zabriceni commune, Briceni district; Naslavcea and Lencăuţi communes, Ocniţa district; Rădenii Vechi commune, Ungheni district; Lozova commune, Străşeni district and within the boundaries of municipality Chişinău. The natural area of distribution of the species comprises Central and Eastern Europe and the Scandinavian Peninsula (Finland) [3].

Pilosella flagellaris is a rare taxon, it grows on hills and slopes with steppe vegetation, grasslands, woodland edges and glades. It is a perennial, European hemicryptophyte. Mesothermic xeromesophile. It blooms in May-June. The fruits ripen in June-July. It propagates by seeds and vegetatively - by stolons (Figure 1).

In 2011-2019, in the framework of a research on rare species of Asteraceae, the populations of the species Pilosella flagellaris that occur in Naslavcea and Lozova communes and in the municipality of Chişinău were studied to identify their

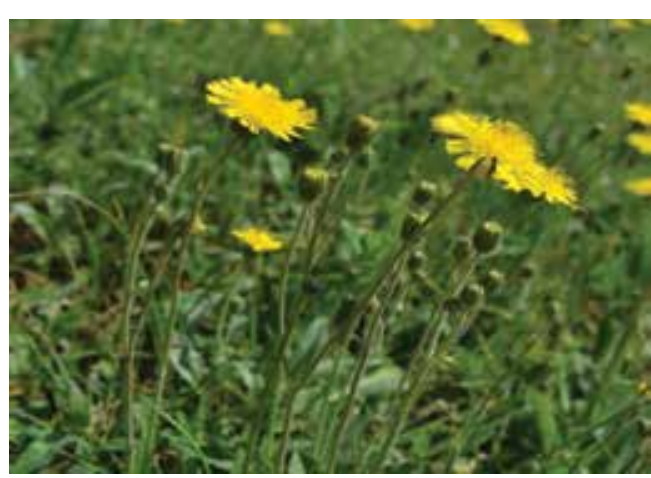

Figure 1. Pilosella flagellaris state, growth conditions and parameters in the natural ecosystems (Figure 1). In terms of conservation, the population found near Naslavcea was in the best condition, because the number of individuals was growing. The population was found on a north-facing slope with petrophyte steppe vegetation, the Pilosella flagellaris grew solitary or in groups over an area of $300 \mathrm{~m}^{2}$, being accompanied by the species: Achillea stepposa Klokov et Krytzka, Agrimonia eupatoria L., Bothriochloa ischaemum (L.) Keng, Carex humilis Leyss., Echium vulgare L., Euphorbia cyparissias L., Pilosella echioides (Lumn.) F. Schultz et Sch. Bip., P. officinarum F. Schultz et Sch. Bip., Potentilla arenaria Borkh., Thymus marschallianus Willd., Teucrium chamaedrys L., Veronica jacquinii Baumg., Stipa pulcherrima C. Koch, etc.

During the field expeditions done in the summer of 2020, Pilosella flagellaris populations were found in three new places: near the Gordineşti commune, Edineţ district, in a sector with calcareous substrate and steppe vegetation; in the valley of the Racovăţ river (the territory of "La Castel” Landscape Reserve), 30 mature individuals were identified, growing in small groups of 2-5 plants; near the Furceni commune, Orhei district, on a slope with steppe vegetation, the species occurs solitarily and in groups, forming small and dense clumps; near Cîzlar village, Leova district, about 20 mature individuals were identified, growing in diffuse groups on an area of about $50 \mathrm{~m}^{2}$.

In the recent years, the conservation status of this species was evaluated according to the IUCN criteria [2], and thus it was classified in the Vulnerable category [VU] A4cde; $\mathrm{B} 2 \mathrm{ab}(\mathrm{iii}, \mathrm{iv}, \mathrm{v})$. The populations of the species are put at risk by excessive grazing and mowing, degradation of steppe sectors and habitat loss.

Pilosella flagellaris is protected in-situ in the territory of "Codru" and "Plaiul 
Fagului" Scientific Reserves and the "Stânca Naslavcea" Geological and Paleontological Monument. Ex-situ, it grows in the sector of rare plants of "Alexandru Ciubotaru" National Botanical Garden (Institute). As conservation measures, we propose to protect the places where this species occurs, to monitor the populations and to record the parameters for the study on their dynamics and to include this taxon in the list of plant species protected by law.

Aknowledgements: The research was supported by the NARD through the project "Research and conservation of vascular flora and macromycobiota of the Republic of Moldova”, 20.80009.7007.22 (contract Nr. 71/PS/2020).

\section{SELECTIVE BIBLIOGRAPHY}

1. Ioniţa O., Negru A. Specii noi de Pilosella Hill. (Asteraceae Dumort.) din flora Basarabiei. In: Akademos, 2010, nr. 4 (19), p. 124-126.

2. IUCN. Guidelines for application of UICN Red List Criteria at Regional Levels: Version 3.0.UICN Species Survival Commission. IUCN, Gland, Switzerland: 2003.

3. Шляков Р. Род Pilosella Hill. В: Флора Европейской части СССР. Ленинград: Наука, 1989, т. 8, c. 375 . 